University of Nebraska - Lincoln

DigitalCommons@University of Nebraska - Lincoln

Faculty Publications, UNL Libraries

Libraries at University of Nebraska-Lincoln

1999

\title{
Theodore Dru Alison Cockerell
}

Sue Ann Gardner

University of Nebraska-Lincoln, sgardner2@unl.edu

Follow this and additional works at: https://digitalcommons.unl.edu/libraryscience

Part of the Library and Information Science Commons

Gardner, Sue Ann, "Theodore Dru Alison Cockerell" (1999). Faculty Publications, UNL Libraries. 109.

https://digitalcommons.unl.edu/libraryscience/109

This Article is brought to you for free and open access by the Libraries at University of Nebraska-Lincoln at DigitalCommons@University of Nebraska - Lincoln. It has been accepted for inclusion in Faculty Publications, UNL Libraries by an authorized administrator of DigitalCommons@University of Nebraska - Lincoln. 


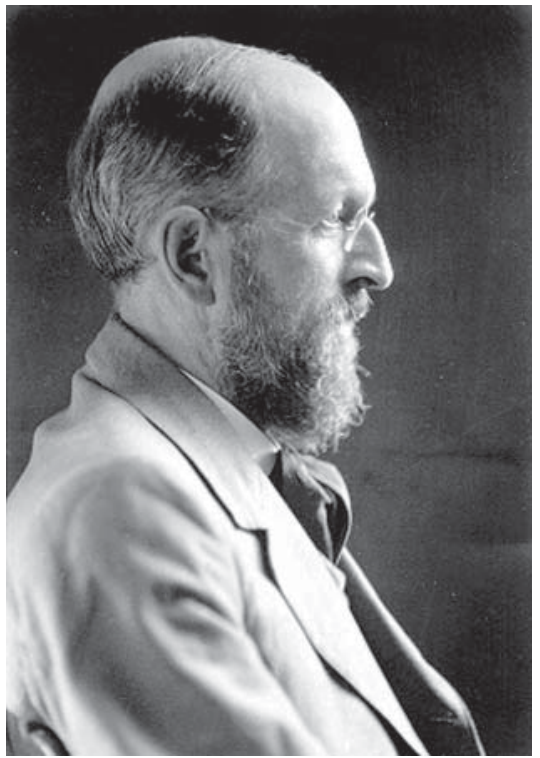

\section{Theodore Dru Alison Cockerell}

(August 22, 1866 - January 26, 1948)

Theodore Dru Alison Cockerell, entomologist and systematic biologist, was born in Norwood, England, the son of Sydney J. Cockerell, a gentleman, and Alice Bennett. After the death of his father in 1878, the family moved to Margate, England. Cockerell attended various schools, including the Middlesex Hospital School, but he did not earn a degree.

"My own interest in natural history began as early as I can remember anything," Cockerell stated in the first installment of "Recollections of a Naturalist," in Bios (6, no. 4 [Dec. 1935]). In that essay he recalled being encouraged as a child by his father and a beloved teacher, Miss Sarah Marshall, who took great care to foster in him a love for science. Cockerell also cited as influential the availability of good, inexpensive natural history books when he was a child, as well as visits to his grandfather's farm and museums. As a result of these factors, when he was a teen he developed an interest in invertebrates, including mollusks, snails, and slugs.
He began to publish papers by the age of twenty, though tuberculosis interrupted his studies. Believing that a mountain climate would be therapeutic, he moved to Westcliffe, Colorado, in 1887 and worked as a biologist. Cockerell entrenched himself immediately in the academic community there and helped to establish the Colorado Biological Association in 1888. His health improved in Colorado, but he returned in 1890 to England, where he worked at the British Museum of Natural History.

There Cockerell met the renowned naturalist Alfred Russel Wallace, with whom he maintained a close personal and professional relationship until Wallace's death in 1913. Their lengthy correspondence included discussions of evolution, natural history, and personal matters.

In 1891 Cockerell married Annie S. Fenn; they had two children, both of whom died before the age of ten. That same year Cockerell left the British Museum and moved to Jamaica, where he secured a position as curator at the Public Museum of Kingston. There he began to describe and name scale insects of the family Coccidae, an interest that he retained throughout his life.

By the age of only twenty-six, in 1892, Cockerell had successfully established himself as an entomologist and was elected a member of the Entomological Society of Washington.

After the untimely death of his wife and a recurrence of his health problems, Cockerell moved to New Mexico in 1893. He exchanged places with C. H. T. Townsend of New Mexico Agricultural College, Las Cruces, where he was appointed professor of entomology and zoology while Townsend took over Cockerell's duties at the museum in Jamaica. In New Mexico Cockerell began to study insects of the order Hymenoptera, including bees, which henceforth comprised the bulk of his work. As with the scale insects, he set about describing and naming bee species and genera.

Cockerell became a U.S. citizen in October 1898, in Doña Ana County, New Mexico. He married Wilmatte Porter, an American biology teacher and naturalist, in June 1900. Over the years they published several papers together on various topics in biology.

From 1900 through 1903 Cockerell taught biology at New Mexico Normal University, Las Vegas. He was then appointed curator at the Museum at Colorado College, Colorado Springs, a post that he held from 
1903 to 1904. At Colorado College, Cockerell completed some important studies on the flowering plant Hymenoxys.

In 1906 Cockerell was appointed to the position of professor of systematic zoology at the University of Colorado. Six years later he was appointed professor of zoology, a position that he held until his retirement in 1934. At Colorado Cockerell conducted research on fossils and fish scales that, like many of his other studies, were primarily taxonomic in nature. In 1923 he was elected president of the Entomological Society of America.

Over the course of his career, Cockerell published nearly 4,000 papers, some of them only a few lines long. Though criticized for his haste in publishing, he persisted in publishing brief papers, appearing to use publication as a method of communication rather than one of recording dicta. Cockerell was also criticized for incompletely consulting, and casually referring to, the literature on any given topic in his papers.

Cockerell's special interest in bees led him to describe and name specimens from the United States, the West Indies, Honduras, the Philippines, Africa, and Asia. He published at least 5,500 names for species and varieties of bees and almost 150 names for genera and subgenera. It has been estimated that this represented over a quarter of all known species of bees during his lifetime.

Above all, however, Cockerell was a general systematist. In addition to extensive studies of bees and scale insects, he published papers on slugs, moths, fish scales, fungi, roses and other flowers, mollusks, and a wide variety of other plants and animals. His publications on nontaxonomic topics in biology included papers on insect coloration, plant and animal distribution, and evolution. He was also a naturalist, composing works, for example, on the general entomology of Colorado and a list of reptiles in part of New Mexico, among many others.

Cockerell was also interested in religion, politics, and poetry and published several works in those fields, many as a book reviewer for Dial (Chicago). He wrote poems and contributed to the debate regarding education in New Mexico around the turn of the century. He wintered yearly in California after his retirement and died in San Diego.
Bibliography: A collection of Cockerell's papers is in the Western Historical Collection at the University of Colorado, Boulder. William A. Weber, University of Colorado Studies, Series in Bibliography, no. 1 (1965), includes a comprehensive listing of Cockerell's publications and offers insights into his motivations for publishing so prolifically and often such brief works. For Cockerell's autobiographical writings, "Recollections of a Naturalist," see Bios, vols. 6-11 (19351940). Obituaries are in Science, 17 Sept. 1948, and the Proceedings of the Entomological Society of Washington 50, no. 4 (Apr. 1948).

\section{Sue Ann Lewandowski [Gardner]}

Published in American National Biography, v. 5, pp. 123-124. Copyright (C) 1999 American Council of Learned Societies. Published by Oxford University Press. Used by per mission. Photo: University of California-Riverside; www.faculty.ucr.edu/ legneref/bcimage/worker.htm . 